\title{
Paideusis
}

\section{The Preparation of Teachers for Roman Catholic schools: Some Philosophical First Principles}

\section{Mario D'Souza}

Volume 9, Number 2, 1996

URI: https://id.erudit.org/iderudit/1073242ar

DOI: https://doi.org/10.7202/1073242ar

See table of contents

Publisher(s)

Canadian Philosophy of Education Society

ISSN

0838-4517 (print)

1916-0348 (digital)

Explore this journal

Cite this article

D'Souza, M. (1996). The Preparation of Teachers for Roman Catholic schools:

Some Philosophical First Principles. Paideusis, 9(2), 5-19.

https://doi.org/10.7202/1073242ar 


\title{
The Preparation of Teachers for Roman Catholic Schools: Some Philosophical First Principles
}

\author{
Mario D'Souza, St. Joseph's College, University of Alberta
}

\section{Contemporary Catholic Education: Some Observations}

The constitutional guarantees of Canadian Catholic education do not appear to be as convincing as they may once have been. The time is now ripe to defend such an education from the position of reason, while acknowledging the arguments made from the position of faith. Catholic education is important to a vast number of Canadians, and acknowledging its philosophical distinctiveness could play a vital role in how such an education could unify a diverse nation such as ours.

Catholic education is crowned by a theology of education. That is its distinctive quality. Contemporary Catholic education, however, has come to rely on theology without much reflection on the various levels of knowledge which enable such a coronation. This reliance on theology, moreover, can only be secured through an integral philosophy which lays the foundation for knowledge of the deepest realities of the human person, the world, and God. Theology assumes this foundation; it cannot construct it. Contemporary Catholic documents on education have enunciated the intellectual principles of Catholic education, thus re-visiting the age-old relation between faith and knowledge, but in a new way. ${ }^{1}$ Church documents have also spoken about the dialogue between faith, culture, and education, and their influence upon the human person; ${ }^{2}$ of the importance of the preparation of the teacher as the communicator of knowledge and truth; ${ }^{3}$ and of the necessity that teacher education must include an "interdisciplinary co-operation," an essential feature of education in the modern world. 4

By relying exclusively upon theology in the pluralistic context, Catholic education has rendered itself indefensible. Theological distinctiveness is a claim that every religious tradition makes; it is hardly peculiar to the Catholic faith. Despite the constitutional protection of Catholic education in Canada, the theological distinctiveness of Catholic education becomes weak in light of the theological distinctiveness of every other religious group represented in the Canadian federation. Furthermore, an exclusive reliance upon theology also makes the integration of faith, culture, and education difficult. Integration, then, becomes the key word.

Integration in education, therefore, primarily means integrating the educand-the subject, in accordance with the demands of his natural end and his supernatural end, with the latter dominating the whole. The philosophy of education consequently cannot be divorced from the theology of education. This implies that education must form the man, not only to know but to know so as to live in the fullest way possible. ${ }^{5}$

Catholic education, like education in general, is driven by the catchwords of "experience" and "relevance." Faith without experience becomes empty formulas, but to reduce faith to experience, mainly the experience of the group, results in a "theological empiricism." 6 Relevance, on the other hand, is achieved by being faithful to the dignity of the human person to be educated, which 
consists of an education of the intellect, the emotions, and moral and social obligations. ${ }^{7}$ Instead, education appears to be taking its cues of relevance from "fashionable topics [which] are flung up from whatever is currently salient and well-publicized, or from the current concerns of government or society (whatever "society" may mean)."8 In this environment, a discussion about concern, commitment, justice, peace, morality, and so on usually gives the appearance of formulating something substantial. In fact, the lack of transcendental or intellectual criteria leads to a democratization and popularization of education bedecked with catch-phrases, jargon, and a frenzy to appear meaningful. ${ }^{9}$ Rendering everything meaningful in education, even the marginal, the one-sided, and the unessential, renders nothing meaningful.

Coupled with this is the contemporary Catholic education which results in the fading of the borders between theology and faith. Now theological teaching becomes the main interpreter of the Gospel; what slowly disappears are the teachings and the teaching authority of the Church. ${ }^{10}$ This is to be expected, for it flows from an almost total dependence upon experience and relevance. Left to themselves, experience and relevance are narrow, limited, and self-congratulatory; they can easily imprison us.

The relationship between faith, culture, and education enables the student to grow as a person, thereby giving Catholic education its distinctive flavour. The contexts of postmodernism and multiculturalism have complicated and challenged this basic premise. For though Catholic education does not identify itself with a particular culture, it does attest to such principles as universal truth, a knowable and enduring human nature, the importance of tradition and authority, and so on. Postmodernism, in particular (and multiculturalism in general), cannot abide such claims and it has become Catholic education's most serious intellectual adversary. If culture is indeed the mantle of the human person in time, then the effects of postmodernism have infiltrated and wrapped the Catholic school and influenced teachers and students alike. One startling consequence is the inability of most contemporary Catholic students to articulate the basic doctrinal, factual, and historical features of the Catholic faith and culture. This reality is hardly limited to students. Many teachers share in this condition, which is more serious ${ }^{11}$

Critics of contemporary Canadian Catholic education have been surprisingly few. ${ }^{12}$ Secularism appears to have eaten away at the distinctive quality of Catholic schools, and it has affected Catholic teachers alike. On the other hand, the defence of contemporary Canadian Catholic education is, with the exception of official Church documents, largely unconvincing. ${ }^{13}$ This defence seems unable to extract and articulate the distinctive quality of Catholic education. Catholic education can never ignore the natural and supernatural destiny of the human person, nor can it be satisfied by the collapse of Catholic education into religious education. What is Catholic about the entire curriculum is a vital question if the analysis of faith and culture is to occur: "sanctity is the aim of Christian education; but learning is the end of the Catholic school."14 While Catholic educators may be quick to state, for example, that there is no such discipline as a Christian mathematics, they appear to be less agile in stating why mathematics is an integral part of the Catholic school. Without it, the school would not be Catholic. But why? 
The overall picture of contemporary Catholic education is not encouraging. The Catholicity of such an education requires significant analysis before it can render itself the act of liberation that it is meant to be. An intellectual crisis in Catholic education stems from at least two sources. First, there is an absence of a spiritual, moral, and intellectual hierarchy to unite the curriculum. Can we speak philosophically about subjects of most worth and least worth without taking away from the integrity of any subject in the curriculum? How do learning and sanctity come together in order for the student to know, for example, that while dates and formulae are important, yet it is more important to know what choices and decisions will make one a good person? Second, a crisis arises when educators and teachers either explicitly deny or implicitly reject official Church teachings. These positions often center around the Church's teachings on sexual and medical ethics. In this regard, students appear to be more knowledgeable of the teacher's beliefs than of what the Church actually teaches. Students have a right to be proficient about the what and the why of official Church teachings before becoming acquainted with dissent. Given this intellectual crisis, it becomes increasingly difficult to speak about the distinctive quality of Catholic education. ${ }^{15}$

\section{Catholic Teacher Education: Some Issues}

Can Catholic student-teachers be adequately prepared outside a Catholic faculty of education? This is not to suggest a Catholic hothouse atmosphere where the concerns of the world are kept at bay. Catholic education is like any other education: it is an education of the intellect and, through intellectual principles, it is an education of the will. It also involves, however, a critique and analysis of society and culture according to the principles of the Catholic faith and the Catholic intellectual tradition. Secular faculties of education have neither the tradition nor the policy to ensure such a preparation. This is not to attribute blame, for they are nondenominational. How, then, can a Catholic student attending such a faculty be prepared to undertake the complex task of Catholic education? Many faculties in Ontario offer a course in religious education for students intending to teach in Roman Catholic schools-a clear example of the exclusive reliance upon a theological basis. This course often becomes remedial in order to compensate for the absence of an education in Catholic doctrine and teachings which should have been carried out in the Catholic school.

Students in faculties of education come from diverse backgrounds and ages and with different beliefs about the art of teaching. 16 Professors, on the other hand, pursuing their own fields of scholarship, do not, by and large, have a knowledge of the basic issues that arise from this pluralistic context, thus making change difficult. ${ }^{17}$ Sharing meanings, goals, and concepts becomes Herculean in a context of such heterogeneity. Contemporary teacher education is also heavy with jargon. ${ }^{18}$ While appearing relevant and contextual, the jargon of "reflection" and "being critical" sounds impressive, but do students possess the intellectual principles to ensure that such terms produce what they promise?

Trends in contemporary education have moved the emphasis from the "unity" and the "integrity" of the human person-involving matters such as the imagination and judgment-to the issue of individual differences. We now 
respect one another because we are different. If, through some magic, individual differences ceased to exist, then, this view implies, so too would our respect for one another. ${ }^{19}$ Despite the allure supplied mainly by multiculturalism, postmodernism eats away insidiously at the fibre of unity of a modern pluralistic state like Canada. "To regard Canadian multiculturalism simply as a means to deal with the diversity of cultures is to regard it minimally."20 Pluralism should be seen as a means of "enriching one's political nature" based upon the realization that all "citizens share the same specific human nature."21 The education of Catholic teachers must go beyond the superficial exaltation of individual differences. Today, such an education has a truly multicultural student-body, and that is its richness. The unity of this body must be grounded in the metaphysical unity of human nature rather than the simplistic answers offered by contemporary Canadian multiculturalism. ${ }^{22}$

The education of student-teachers destined for Catholic schools must include a development of their knowledge, skills, dispositions, norms, attitudes, and religious beliefs. Naturally, such an education must use the various resources of teacher education. But it must also prepare the teacher to step into a living and vibrant tradition, both past and present. The first requirement, then, is a substantial knowledge of, and a commitment to, the Catholic faith. While the Catholic school is primarily concerned with the intellectual development of its students-this, indeed, is its primary aim-nonetheless, such a school cannot be effective and will not communicate an integral intellectual development unless members of its teaching staff are readily committed to their faith. Second, in order for the student to make choices grounded in fundamental values through the cognitive and affective faculties, ${ }^{23}$ the teacher needs to exert a causal influence upon the student. This requires a specific education and runs contrary to one of the primary fallacies of Catholic education: the "anybody-can-do-it" fallacy. 24

\section{A Note on the Role of Catholic Education in a Pluralist Society}

Catholic education must play its role in unifying a pluralist state, and it must do so through the development of an integral humanism, one which considers the person as a unity of intellectual, moral, social, and religious dimensions. One essential feature is that of human equality by way of a common human nature. ${ }^{25} \mathrm{By}$ appealing to this human nature and to the dignity of the intellect, Catholic education can become a primary force in unifying a diverse nation. In its quest for knowledge and truth, such an education rises above religious, political, and ideological divisions to demonstrate the importance of humanizing its students, whatever their religious affiliation. In its traditional emphasis on being and the claim that truth is convertible with the full reality of being, a Catholic philosophy of education can show the epistemological importance of a unified and diverse curriculum and how this unity and diversity play a vital role in humanizing all students, irrespective of their religious affiliation. ${ }^{26}$ It seems that a strong philosophical position will prove to be more convincing about the particular identity of Catholic education rather than arguments stemming from constitutional guarantees which becomes difficult to hold up to the light of a pluralist and diverse nation like Canada. 


\section{Principles for the Education of Catholic Teachers}

A Catholic philosophy of education is based upon a philosophy of life. ${ }^{27}$ Such a philosophy insists that, though education commences with experience, it is completed in reason. ${ }^{28}$ Reason, therefore, becomes the unifying force of the student's experience. Four principles rooted in reason are now proposed for the education of Catholic school teachers.

\section{(i) The Teacher's Love of Truth Unifies the Student's Experience}

The primary direction of the intellect is towards the truth. The teacher ensures the student's subjective development through the objective validity of truth. ${ }^{29}$ The student's mind, says St. Thomas Aquinas, exists in active as opposed to passive potentiality. ${ }^{30}$ The student's intellect is the main agent; the teacher is an exterior agent enabling the intellect to act and grasp the truth. Through the instrumentality of the truth-the truths particular to the individual subject as well as the lived truths of the Catholic faith-the teacher leads the student from the known to the unknown. Truth, therefore, is not limited to the imparting of intellectual knowledge, and neither is education. The teacher must possess and cherish an expansive notion of truth to include learning and knowledge, but also, and by way of implication, an appreciation of how leaming and knowledge enable the living out of truth in one's whole life. The teacher, then, through a devotion to the particular subject as well as a commitment to the tenets of the Catholic faith, becomes a vibrant symbol in communicating the truth: "A truth which is loved by the teacher, and communicated in such a way that it is seen to be something valuable in itself, then becomes valuable to the student." 31

Education in Catholic philosophy is seen as a systematic introduction to the life of reason. Obviously, then, education is concerned with reality, with what is. Hence, teaching is nothing if it is not founded on truth. The teacher's instrumentality does not cause truth; it enables the student to acquire a knowledge of truth. ${ }^{32}$ The subjectivity of the student and the objectivity of the teacher give truth a living character. The teacher does possess a knowledge of the truth, albeit in a limited way. Without the objective foundation of truth, however, knowledge would become purely subjective and virtue would be confused with self-knowledge. Without the subjective dimension, however, knowledge would become a collection of impressions or sensations and virtue would become mere social dexterity. ${ }^{33}$ Thus, St. Thomas says that, though discovery and instruction are the two ways of acquiring knowledge, the latter is the superior of the two because the teacher has a knowledge of the truth, or, in the words of scholastic philosophy, "the teacher [has] the science in act which the student has only in potency." 34 Moreover, the words of the teacher have a greater power to convince than does personal discovery because such words convey the wisdom of a reflective mind as well as a personal commitment. A Catholic philosophy of education, therefore, while recognizing the value of discovery, places a higher value on education through instruction. A logical presentation of the subject matter contributes much towards the acquisition of truth. Such a presentation must be secured in general principles which enable the mind to move toward particular conclusions. The teaching mandate is based upon this simple feature. The teacher's principles and convictions are, therefore, invaluable for education. 
Ultimately, a good teacher loves to teach because of the love of truth. This is the teacher's primary motivation. Truth provides the reality and identity for the integration of the various parts of the curriculum. "S5 "Since truth includes being and being is not chaotic, each truth has its proper place, which is known to the degree that truth itself is known." 36 Truth enables the student to grow in the life of the mind, to discern knowledge of more worth and less worth when related to the totality of life, and the realization of how truth sets one free. The teacher's teaching of truth will engage the student's intellect, and this engagement must involve a commitment to the truth as well as the implications of such a commitment.

Catholic teacher education cannot present the truth of disciplines in a vacuum. Students must come to appreciate the truth in each discipline so as to link truth to the commitment of life. An integral Catholic school curriculum must show how truth arises from the physical world-from the senses-and moves through the various stages of reality to supreme truth: a knowledge of God, or faith. Only the unity of truth will make this possible, and this unity must first exist in the mind and heart of the Catholic teacher. The Catholic student-teacher, therefore, will require a specific instruction in developing such an epistemology. Furthermore, given the unity of truth, such an epistemology cannot ignore the place of faith, for all truth finds its source of unity in the ultimate truth: God. ${ }^{37}$

(ii) The Teacher's Knowledge Unifies the Student's Experience

Experience without unity or organization is not educational. It is the conclusions and implications drawn from experience which give it educational import:

In order to discover the implications of our knowledge, it is not enough simply to have experiences. One must also be able to see that truths previously acquired apply to the experiences, and be able to state, at least vaguely, why they apply. ${ }^{38}$

Catholic education stresses the education of the whole person. The school is the privileged instrument of dignifying the unity of the student through the education of the intellect. This unity-human, professional, and religious-is not enhanced by the fragmentation or isolation of various branches of knowledge. The teacher's principles-of the subject matter, the Catholic faith, and the epistemology referred to earlier-enhance this unity and, hence, growth of the whole person. 39

A good teacher cannot ignore students' feelings about their experiences. The pluralistic environment has made the unity of these feelings a difficult task. Most students, however, are concerned about their self-image and the unity and control of their lives. Amidst these diverse experiences, the teacher, today more so than ever, is an essential guide in providing the student with human confidence over doubt and skepticism. The Catholic teacher, convinced of the mystery of the human person, assists the student toward a total formation by an education of the intellect. Teaching in this context is more than learning and listening: it is a transformation of the student's understanding. The teacher's knowledge and specialization enhance this transformation. The teacher's own commitment to truth and integrity-intellectual, professional and religious-is a 
transformation in more than a theoretical or intellectual way; it situates truth in the realm of human unity. This comes from an adherence to the Catholic philosophy of life, one that unites theory and practice. ${ }^{40}$

The Catholic teacher unites the experiences of the student in two other important ways: through the unity of the curriculum and through a commitment to the Catholic faith. By emphasizing the different intellectual disciplines and, thus, emphasizing a diversity of experiences, the curriculum contributes to the unity of truth and knowledge and, thus, the experience of being human: "For he who is wise understands how all things are related to each other and to God from whom they come and to whom they go." 41

The teacher teaches by virtue of a comprehensive approach to knowledge, but, more importantly, by virtue of the experience of knowing. The teacher's knowledge is not only "about" an object or a discipline, it is also "of" it. Comprehensive knowledge includes knowing what a thing or discipline is and what it does. Comprehensive knowledge in Catholic education must also recognize a hierarchy in the curriculum, a hierarchy based upon moral, intellectual, and spiritual values. Such a hierarchy enables education to achieve its immediate end: the education of the intellect. Such an education must assist the student to draw implications and make judgments in order to bring about a unity in life. Catholic education maintains that such a unity has a natural hierarchical structure. ${ }^{42}$ This hierarchy also enables Catholic education to assist the student towards the ultimate end: union with God. The teacher, therefore, must show how a particular subject maintains an intimate relationship with this hierarchy, not dogmatically or by being authoritarian, but by enlightening the mind of the student. The manifestation of human personality is essentially rational; thus, the subjective integration of the student will be achieved through reason. ${ }^{43}$ The student is a homogeneous whole. The teacher's ability consists in introducing the student to the heterogeneity of the curriculum while maintaining the student's unity. The curriculum must widen the student's experiences but not spread them out. This is achieved by stressing the virtues of discernment and vision as opposed to simply the acquisition of facts and opinions. So, while there is no such discipline as a Christian mathematics, there is a way of teaching mathematics as an integral discipline in a Catholic school. Jacques Maritain explains this method:

[The teacher] will convey to the student and awaken in him something beyond mathematics, astronomy or engineering: first, a sense of the proper place of these disciplines in the universe of knowledge and human thought; second, an unspoken intimation of the immortal value of truth, and of those rational laws and harmony which are at play in things and whose primary roots are in the divine intellect. ${ }^{44}$

A Catholic philosophy of education, ultimately, cannot exist apart from a Catholic theology of education. ${ }^{45}$ It is the adherence to such a theology that enables the integrative process among subjects of the curriculum that do not immediately lend themselves to a Catholic philosophy of life-for example, mathematics. It is, as Maritain says, why it is taught and how it is taught that gives mathematics an essential place within the unity of the Catholic school curriculum. This is made possible by the teacher's constant striving to unify intellectual and human experience. Thus, the curriculum is a unity concerned with the unity of the human person, a unity achieved through diversity. 
The teacher's commitment to the Catholic faith is another way of unifying the student's experience. The teacher enjoys a privileged opportunity in presenting the whole Christian message. It seems that too often today the professional reality of this fact is ignored in favour of some compulsive desire on the part of the teacher to share with students his or her personal dissent from and objections to the Catholic faith. On the contrary, Catholic teachers possess a special responsibility to unify the student's experience at a theological level: what it means to be a practising and committed member of the Church. This is achieved by the teacher's own commitment to the Catholic faith as well as showing how a comprehensive development of reason is essential to the student's faith. The truth at various levels of the curriculum must gradually lead to a knowledge of Truth. Thus, the teacher's fidelity to the Catholic faith plays a vital role in seeing human knowledge in the light of the Gospel and looking upon the Catholic school as a community of faith ${ }^{46}$ The issue of academic freedom in Catholic institutions is a hotly debated subject with strong positions taken up on either side. ${ }^{47}$ Catholic documents, however, remain firm on the conviction that all Catholic teachers must be role models in the practice and life of the Catholic faith. ${ }^{48}$

\section{(iii) The Teacher's Method Unifies the Student's Experience}

Catholic education maintains that the student is the efficient cause of his or her own leaming. ${ }^{49}$ The teacher, however, also exerts an efficient causality upon the learner, and is, therefore, not dispensable ${ }^{50}$ The teacher does not transfer knowledge to the students. Rather, the teacher enables students to achieve similar learning for themselves. The teacher's pleasure consists in communicating to the student the seeds of "intellectual life, knowledge, truth." 51 This pleasure is the chief ingredient of the teacher's method. The call for formulating good reasons for educational action cannot be separated from this primordial sense of the pleasure of teaching. Developing rational justifications for such action is rendered meaningless apart from the communication of intellectual life, knowledge, and truth.

The method of the Catholic teacher must include an inter-disciplinary approach, one which is united in the degrees of knowledge, a hierarchy of knowledge, values, and truth, as well as a unity that is grounded in a "spiritual universality." 52 The curriculum in a Catholic school should be based upon such hierarchies, upon what one philosopher called "subjects of most worth" and subjects "of least worth,"- not in terms of their value per se, but in terms of the spiritual nature of the student as a person and acknowledging the importance of "abstract insight and intellectual judgment." 53 Topics such as the human person, family, society, the evolution and constitution of human history, and other contemporary cultural influences form the crucial matter of an inter-disciplinary method. This element of the teacher's method is not reserved solely for teachers of religion and theology. The hierarchical nature of the curriculum matures through the permeation of an inter-disciplinary method. Student-teachers will need some preparation for this to occur.

Teaching is an art and is, therefore, manifested in the active life. Everything that the teacher does is evident through the active life. Teaching, however, is rooted in the contemplative life-that is, the contemplation of truth (all truth) 
and knowledge, and their relation to the development of the human person. In Gilson's words, "education is a field of human activity in which it is most necessary that speculation go before action." 54 The contemplative component enables the teacher to discover the truth through reflection. The teacher needs the active element of teaching in order to communicate these discovered truths to the student. ${ }^{55}$ The contemporary fixation with method and methodology needs to take a sober second look at the primacy of content over method. The teacher's primary concern for wisdom and truth is what enables the student to move from principles to conclusions: "The words of the teacher represent his concepts, and concepts are the distilled wisdom of a reflective mind."56 This intellectual nourishment not only enables the abstractive nature of the student's intellect to become active-that is, the mind's ability to rise from and through the different degrees of knowledge ${ }^{57}$-but is also a vital means of communicating the doctrinal component of the Catholic faith.

It needs to be pointed out, however, that teaching is not merely a stimulation of the mind. In moving from the unknown to the unknown, the student is not at the same level in every act of cognition. The student, therefore, is dependent upon the teacher's possession of a complete and perfect knowledge of what he or she teaches-a knowledge which is communicated methodically and in accordance with the student's intellectual capacity. ${ }^{58}$ While students can learn from teachers whose knowledge is limited, the unity of the student's experiences is greatly dependent upon the stronger knowledge that the teacher possesses. Ultimately, the teacher's method is concerned with communicating meaning, insight, and understanding precisely by appealing to the active potency of the student's mind. The teacher's method, therefore, is essential to the experience of learning. Thus, the teacher's method is steeped in contemplative content and manifested in the action of teaching.

\section{(iv) The Teacher's Worldview Unifies the Student's Experience}

The Catholic school seeks to develop a Christian view of reality. The primary responsibility for developing such a vision of reality rests with the Catholic teacher. This is achieved, first and foremost, through an adherence to the Catholic faith and by developing a Christian sense of community within the school. Second, it is achieved through the teacher's worldview which includes a reflection on the nature and purpose of education and how the human person-the student-is perfected through education. The development of a Catholic worldview should not rest at the mercy of school boards, politicians, or even parents. While it seeks their co-operation and good will, it must, nevertheless, constantly struggle to remain faithful to the Christian development of the whole person: "As concerns the social changes in the contemporary world, teachers have neither to make the school into a stronghold of the established order nor to make it a weapon to change society." 59 The professional identity of Catholic teachers includes their social beliefs-beliefs that have constantly been stressed by the popes of this century in their various social encyclicals ${ }^{60}$-and the education of such teachers must involve some scrutiny and reflection of such beliefs in light of Catholic teaching. 
Culture is the single most important feature molding the teacher's worldview. The shifts in contemporary culture includes the relacement of a western culture concerned with the contingent and the particular. ${ }^{61}$ Postmodernism defines culture through the single rule that there are no rules. Culture, then, swims or drowns in accordance with this rule. ${ }^{62}$ Different concepts of culture and different concepts of what constitutes culture create different orders of relevance. The Catholic school cannot be isolated from nor defined by such a definition of culture. Culture in the Catholic tradition consists of all those human creations that constitute a social way of life, one that has a tradition embedded in institutions and has moral standards and principles. In this regard, a Christian culture is a social way of life based upon the Christian faith. ${ }^{63}$

The critical evaluation of culture, its relationship to the whole of Christian life, and especially the call to Christian perfection will depend largely upon the teacher. Whereas the Catholic school cannot and should not be isolated from the culture of its day, it must exemplify the principles required to evaluate culture, show when it demeans the human person, when it enables integral growth, and when it is either neutral or post-Christian. Faith, culture, and intellectual education are the building blocks of the Catholic school. They depend upon a particular philosophy of life that is able to put them in the right relationship and right order with one another. Catholic educators cannot overlook the reality that the Church and parents are the two other pillars of Christian education-indeed, parents are the primary educators. In the area of formal education, however, faith, culture, and intellectual education depend upon the authority of the teacher to lead the student from the principles contained therein to the conclusions constituting a Christian culture. This will only come about if the teacher's worldview and beliefs are in accordance with such principles. The unity of the student's experiences is dependent upon this fact.

The crisis today is not a crisis of Catholicism but of modern culture and civilization. This results in the fragmentation of the student's cultural experiences. The teacher's worldview is vital in leading the student through the contemporary cultural maze. This must be achieved neither by rejecting contemporary culture nor by reducing it to a matter of personal taste. The teacher needs to take a stand about issues of contemporary culture, one that is based upon intellectual principles and conclusions, and, therefore, one that appeals to the intellect and judgment of the student. A failure to so situate this critique and attempting to substitute it with sheer authority or blind faith will result in a disconnection of faith, learning, and intelligence. A Christian worldview seeks to inculcate a manner of knowing how to know reality. For this and for the unity of one's cultural experience, the student is dependent upon the teacher's worldview in coming to know reality.

\section{Conclusion}

The crisis in contemporary Catholic education is to be traced to the disconnection of faith, culture, and learning, both in the student and the teacher. By way of example of this disconnection, a curriculum where religious education or theology becomes isolated from the rest of the curriculum implies no bearing or relationship with it. A second example is the trend towards very early specialization in education which ignores what Maritain called the distinction between the education of "natural intelligence"-concerned with a univer- 
sal knowledge best exemplified in a basic liberal education-and education of the "intellectual virtues"-preparing a student for a particular field of activity. ${ }^{64}$

Furthermore, this disconnection can be traced to the danger in Catholic education's exclusive reliance upon theology. The critique of culture and the development of a Christian worldview will only benefit from theology if they have been previously secured on the foundation of the expansiveness of the various branches of knowledge: of how each division of knowledge has a particular way of knowing and coming to know.

The cultural, intellectual, and doctrinal issues that face contemporary Catholic teachers are challenging, but such issues are also what gives Catholic education its vitality. It is an integral education pursued from different perspectives, and nourished from all of knowledge, learning, and culture. To undertake such a task, however, will require special conditions and institutions. If Catholic education does have a distinctive quality-a quality that must demonstrate its epistemological and philosophical relevance in a pluralist society-then this must be reflected in the intentional and special education of its teachers.

The philosophical preparation of contemporary Canadian Catholic school teachers is significantly deficient and calls into question the distinctive quality of Catholic education, especially in uniting a pluralist student body. Indeed, it is questionable whether such teachers could isolate such distinctive features. If institutional education is primarily an education of the intellect and, hence, reason, then a total reliance upon theological principles fails to communicate the distinctive quality of such an education within a pluralist setting. Furthermore, students emerging from Catholic schools who have not been taught about the dangers of the disconnection between faith, culture, and learning will, in turn, fail to see the distinctive quality about their education.

The paradigm of contemporary Catholic education is almost entirely theological, and the education of its teachers appears to be conducted from this perspective. This is evidenced by the kinds of in-service and pre-service programmes that Catholic teachers receive, by the lack of a truly philosophical basis in Catholic school boards, and in recent literature which does not tackle the heart of this philosophical basis and the subsequent theological coronation. ${ }^{65}$ The attempt to introduce a foundations course in the preparation of Catholic school teachers will fail if it is simply added on from the outside without attempting to integrate it through out the curriculum. On the other hand, this theological trend can be compared with the analysis of Catholic education approximately thirty years ago which took a far more serious, scholarly, and intellectual approach to the issues and construction of such an education.66 Perhaps the disfavour of a traditional scholastic philosophy is partly to blame for this shift, and perhaps it is a shift away from an intellectual approach to education as opposed to a more popular and charismatic one. Whatever the reason, this paper has attempted to show why this is not sufficient. It has also attempted to show that an exclusive reliance upon theology without the necessary philosophical pillars fails to convince students, teachers, and indeed parents, of the importance of the theological foundation. The preparation of teachers for Canadian Roman Catholic schools must be intentional, much more so than it is at the present time. And it must be a preparation based on philosophical first principles which secure the unity, diversity, and distinctive quality of all knowledge. 
It is the philosophy of Catholic education that enables a theology of Catholic education to secure the appropriate means and ends for the education of the human person-the student. It is such a philosophy that enables the student to come to know reality and the different ways of coming to know reality. Only such a philosophy can secure a knowledge of reality at these different levels, and only such a philosophy can show why knowledge is incomplete without knowing reality at these different levels. Without these different levels of knowledge, education is not universal. It is not Catholic.

\section{Notes}

${ }^{1}$ See Mark J. Hurley, "Commentary," in De Educatione Christiana (New Jersey: Paulist Press, 1966), 47, 52, \& 108. See also De Educatione Christiana, $128, \& 39$.

${ }^{2}$ See The Catholic School (Rome: The Sacred Congregation for Catholic Education, 1977); Lay Catholics in Schools: Witnesses to Faith (Rome: The Sacred Congregation for Catholic Education, 1982); and The Religious Dimension of Education in a Catholic School (Rome: The Sacred Congregation for Catholic Education, 1988).

${ }^{3}$ See Lay Catholics in Schools, no. 16.

${ }^{4}$ The Religious Dimension of Education in a Catholic School, no. 64.

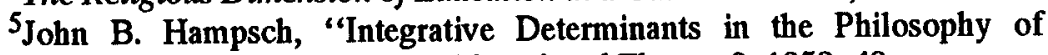
Education of St. Thomas Aquinas," Educational Theory, 9, 1959, 40.

6Joseph Cardinal Ratzinger, "Sources and Transmission of the Faith," Communio: International Catholic Review, (Spring)1993, 22.

${ }^{7}$ See Gerald Weinstein and Mario D. Fantini (eds.), Toward Humanistic Education: A Curriculum of Effect (foreword by Edward J. Meade, Jr.) (New York: Praeger Publishers, 1970), 19-22.

${ }^{8}$ John Wilson and Barbara Cowell, Taking Education Seriously (London, Ontario: The Althouse Press), 1989, 12-13.

${ }^{9}$ See Ibid., 13.

${ }^{10}$ See "Problems in Catechesis Today: An Interview with Joseph Cardinal Ratzinger," translated by Peter Verhalen, Communio: International Catholic Review, (Summer) 1984, 150.

${ }^{11}$ See Kenneth Westhues, "Catholic Separate Schools: An Ambiguous Legacy," Grail, I, March 1985, 55 \& 60 . See also Leslie J. Francis, Carolyn Wilcox, and Jeff Astley, "What is a Christian? Investigating the Understanding of 16-to-19-Year Olds," in Jeff Astley and David Day (eds.), The Contours of Christian Education (Great Wakering, Essex: McCrimmons, 1992), 329-336. See also, Reginald W. Bibby and Donald C. Posterski, Teen Trends: A Nation in Motion (Toronto: Stoddart, 1992), 50-56, \& 247-271.

${ }^{12}$ See Kenneth Westhues, "Public vs. Sectarian Legitimation: The Separate Schools of the Catholic Church," Canadian Review of Sociology and Anthropology, 13, 1976, 137-151.

${ }^{13}$ See Michael Higins et al. (eds.), Catholic Education: Transforming Our

Vision: A Canadian Perspective (Ottawa: Novalis, 1991). See also Larry Trafford, “What Makes Education Catholic?" Grail, 9, 1993, 27-49. 
${ }^{14}$ Lawrence E. Lynch, Intellectual Curiosity in Catholic Schools (Toronto: The English Catholic Education Association of Ontario, 1957), 9.

${ }^{15}$ See Robert B. Nordberg, "Curricular Integration in Roman Catholic Education," Religious Education, 82, 1987, 127-142.

${ }^{16}$ See Marvin F. Wideen and Patricia Holborn, "Teacher Education in Canada: A Research Review," in Richard P. Tischer and Marvin F. Wideen (eds.), Research in Teacher Education: International Perspectives (London: The Falmer Press, 1990), 13.

${ }^{17}$ See David Hopkins, "Drift and the Problem of Change in Canadian Teacher Education," in David Hopkins and Ken Reid (eds.), Rethinking Teacher Education (London: Croom Helm, 1985), 110.

${ }^{18}$ See Daniel P. Liston and Kenneth M. Zeichner, Teacher Education and the Social Conditions of Schooling (New York/London: Routledge, 1991), 38.

${ }^{19}$ See John Pilley, "Educational Theory and the Making of Teachers," Educational Theory, 3, 1953, 34.

${ }^{20}$ Mario D'Souza, "Toward a Canadian Political Philosophy of Education," Paideusis, 7(2), 1994, 17.

${ }^{21}$ Ibid., 19.

${ }^{22}$ For a scholastic discussion on the equality of human nature, see Jacques Maritain, Ransoming the Time, translated by Harry L. Binsse (New York: Gordian Press, 1972), Chapter I, "Human Equality," 1-32.

${ }^{23}$ See James A. Duplass, "The Marginal Difference in Catholic Education," Religious Education, 70, 1975, 281.

${ }^{24}$ Nordberg, "Curricular Integration," op. cit., 138.

${ }^{25}$ See Jacques Maritain, Education at the Crossroads (New Haven and London: Yale University Press, 1943), 7-8.

${ }^{26}$ See George F. McClean, "The Unity of Truth: Context of an Integrated Catholic Education," in George F. McClean (ed.), Philosophy and the Integration of Contemporary Catholic Education (Washington: The Catholic University of America Press, 1962), 10.

${ }^{27}$ The case for a Christian philosophy, per se, is well articulated by Jacques Maritain, An Essay on Christian Philosophy, translated by Edward H. Flannery (New York: Philosophical Library, 1955), especially pages 11-13. See also Etienne Gilson, The Philosopher and Theology, translated by Cecile Gilson (New York: Random House, 1962), especially pages 175-199.

${ }^{28}$ See Maritain, Crossroads, 46.

${ }^{29}$ See Robert J. Slavin, "The Thomistic Concept of Education," in Robert E. Brennan (ed.), Essays in Thomism (New York: Sheed \& Ward, 1943), 318.

${ }^{30}$ See St. Thomas Aquinas, "De Magistro," in Mary Helen Mayer, The Philosophy of Teaching of St. Thomas Aquinas, introduction by Edward A. Fitzpatrick (Milwaukee, WI: The Bruce Publishing Company, 1929), 51-52.

${ }^{31}$ The Religious Dimension of Education, no. 107, op. cit.

${ }^{32}$ See Herbert Johnson, A Philosophy of Education (New York: McGraw Hill, 1963), 210.

${ }^{33}$ See Mayer, The Philosophy of Teaching, op. cit., 135-135.

${ }^{34}$ Pierre H. Conway, Principles of Education: A Thomistic Approach (Washington: The Thomistic Press, 1960), 150.

${ }^{35}$ See McClean, "The Unity of Truth," op. cit., 11-12. 
${ }^{36}$ Ibid., 24.

${ }^{37}$ On the unity of truth and its relationship to religious faith or God, see McClean, "The Unity of Truth," op. cit. See also Eugene Kevane, "Philosophy and the Unity of the Curriculum," in McClean (ed.), Philosophy and the Integration of Contemporary Catholic Education, op. cit., 232 \& 242.

${ }^{38}$ Robert S. Sokolowski, "De Magistro: The Concept of Teaching According to St. Thomas Aquinas," in John K. Ryan (ed.), Studies in Philosophy and the History of Philosophy, Vol. 1 (Washington, DC: The Catholic University of America Press, 1961), 174.

${ }^{39}$ See The Catholic School, no. 29, op. cit..

${ }^{40}$ See Slavin, "Thomistic Concepts of Education," op. cit., 329.

${ }^{41} \mathrm{John}$ W. Donohue, St. Thomas Aquinas and Education (New York: Random House, 1968), 88.

${ }^{42}$ On the hierarchy of the curriculum, see Maritain, Education at the Crossroads, op. cit., 36-39 \& 58-87. For a contemporary and secular approach to a hierarchy in the curriculum, see Robert E. Proctor, Education's Great Amnesia: Reconsidering the Humanities from Petrarch to Freud (Bloomington and Indianapolis: Indiana University Press, 1988), 170-199.

${ }^{43}$ See Hampsch, "Integrative Determinants," op. cit., 37.

44Jacques Maritain, The Education of Man: The Educational Philosophy of Jacques Maritain, edited with an introduction by Donald and Idella Gallagher (Westport: Greenwood Publishers, 1976), 136-137.

${ }^{45}$ See Harold A. Buetow, The Catholic School: Its Roots, Identity, and Future (New York: Crossroad, 1988), 6-7.

${ }^{46}$ See The Catholic School, nos. 17 \& 53, op. cit.

${ }^{47}$ See, for example, Joseph J. Annarelli, Academic Freedom and Catholic Higher Education, foreword by Charles E. Curran (New York: Greenwood Press, 1987). See also Thomas F. O'Meara, "The Department of Theology at a Catholic University," in Theodore M. Hesburgh (ed.), The Challenge and Promise of a Catholic University (Notre Dame: University of Notre Dame Press, 1994), 243-256.

${ }^{48}$ See Lay Catholics in Schools, nos. 9, 15, 18, 20, 40, \& 49, op. cit. See also John Paul II, "Ex Corde Ecclesiae-The Apostolic Constitution on Catholic Universities," Origins: CNS Documentary Service, October 4, 1990, Vol.20.

${ }^{49}$ See Anthony D. Gulley, The Educational Philosophy of St. Thomas Aquinas (New York: Pageant Press Inc, 1961), 69-79.

${ }^{50}$ See Ibid., 80-97.

${ }^{51}$ Etienne Gilson, The Eminence of Teaching (Toronto: The English Catholic Education Association of Ontario, 1953), 8.

${ }^{52}$ See Maritain, Education at the Crossroads, op. cit., 80. See, also, Maritain, The Education of Man, op. cit., 45, 54, 56, 58 \& 97.

${ }^{53}$ Maritain, Education at the Crossroads, op. cit., 151 \& 153.

${ }^{54}$ Etienne Gilson, "Education and Higher Learning," in Anton C. Pegis (ed.), A Gilson Reader: Selected Writings of Etienne Gilson (Garden City, New York: Image Books, 1957), 312.

${ }^{55}$ See Etienne Gilson, "The Christian Teacher," in A Gilson Reader, op. cit., 224.

${ }^{56}$ Mayer, The Philosophy of Teaching, op. cit., 141. 
${ }^{57}$ See Jacques Maritain, Distinguish to Unite or The Degrees of Knowledge, translated by Gerald B. Phelan (New York: Charles's Scribner's Sons, 1959), 35-36. See also Jacques Maritain, A Preface to Metaphysics: Seven Lectures on Being (New York: Sheed and Ward, 1946), 81-85. 102-105.

${ }^{58}$ See Gully, The Educational Philosophy of St. Thomas Aquinas, op. cit.,

${ }^{59}$ Maritain, The Education of Man, op. cit., 59.

${ }^{60}$ See John Paul II, Laborem Exercens-On Human Work (Boston: St. Paul Editions, 1981). See also John Paul II, Sollicitudo Rei Socialis-Concern for the Social Order (Sherbrooke: Editions Paulines, 1987) and Centesimus Annus-The Social Teaching of the Church (Sherbrooke: Editions Paulines, 1991).

${ }^{61}$ See Brendan Carmody, "A Context for the Catholic Philosophy of Education," Lumen Vitae: International Review of Religious Education, 36, $1981,50$.

${ }^{62}$ See Chris Jenks, Culture (London: Routledge, 1993), 137.

${ }^{63}$ See Christopher Dawson, The Historic Reality of Christian Culture (New York: Harper \& Row Publishers, 1960), 13 \& 14.

${ }^{64}$ See Maritain, The Education of Man, op. cit., 48-49 \& 72-73.

${ }^{65}$ See Caroline DiGiovanni (ed.), The Philosophy of Catholic Education (Ottawa: Novalis, 1992); James T. Mulligan, Formation for Evangelization: Reflections of a Catholic Educator (Toronto: Novalis, 1994); and Michael Higgins et al (eds.), Catholic Education: Transforming Our World: A Canadian Perspective, op. cit..

${ }^{66}$ See George F. McClean (ed.), Philosophy and the Integration of Contemporary Catholic Education, op. cit.. 